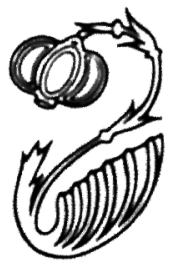

\title{
Est locus uni cuique suus: City and Status in Horace's Satires 1.8 and 1.9
}

plane multum mihi facetiarum contulit istic Horatius Flaccus, memorabilis poeta mihique propter Maecenatem ac Maecenatianos hortos meos non alienus.

(Fronto, Ep. ad M. Caes. 1.8)

Clearly. Horatius Flaccus supplied me with much wit to that end, an unforgettable poet and no stranger to me on account of Maecenas and my gardens of Maecenas.

Fronto, writing some 150 years after Horace's death, nevertheless still perceived a close connection between Horace's poetic style, his patron Maecenas, and Maecenas' gardens. The famous teacher had come into possession of the gardens and took pleasure at the thought that, through them, he had something in common with Rome's most widely accomplished poet. These gardens are featured in the Satires, juxtaposed with Rome's downtown, providing an enticing glimpse of the contrast between urban and suburban in post-Republican Rome. Two poems in particular have caught the attention of those who would recreate Rome from Horace's words. In Satires 1.9, Horace narrates an interrupted stroll down the Sacra Via, Rome's busiest street, which he contrasts with the serene atmosphere of Maecenas' home. Satires 1.8 offers a glimpse of the gardens themselves in a

This paper has benefited from the criticism and suggestions of many readers. I wish to thank Carole Newlands. Anthony Corbeill. Pamela Gordon, Kirk Freudenburg. Daniel Hooley, Susan Curry, Gregory Starikowsky, and the anonymous readers of Classical Antiquity for their generous help.

Classical Antiquity. Volume 20. Number 1. pages 165-192. ISSN 0278-6656(p); 1067-8344 (e).

Copyright 02001 by The Regents of the University of California. All rights reserved.

Send requests for permission to reprint to: Rights and Permissions.

University of California Press, 2000 Center Street. Ste 303, Berkeley, CA 94704-1223. 
state of change, as a statue of Priapus describes the atmosphere before and after Maecenas' renovation.

Scholarship on the topography in the Satires has been concerned with precise locales. In Satines 1.9, for example, scholars have iried to reconstruct Horace's exact path through the Forum Romanum.' Others. casting their nets more broadly. have examined the sum of locales cited in Horace's satiric poetry. sketching not only a map of his satiric interest but also a silhouette of Rome in the thirties.' The preference Horace shows for the Campus Martius and the Forum over the new monuments in the emerging Augustan city displays the satirist's caution about political themes in turbulent times.'

My approach differs somewhat from these. This paper examines the moral and aesthetic encoding of the urban landscape in Sarires Book I. Locations in the Satires should be read not so much as autobiographical statements about Horace's movements in Rome, but rather as functions of other themes and motifs in the poems. ${ }^{4}$ Examining Satires 1.9 and 1.8. I shall argue that the city center (the most public place in Rome) and the gardens of Maecenas (a place newly made private) provide the poet an arena for indinect meditation about his movement from the wider Roman community into the selective circle of Maecenas, and about the relationship between his poetry and his patron.' A decade ago Jaeger identified topography as a way to measure Horace's success: the closer he grows to Maecenas. the more exposed he is downtown-hence the difierence between his anonymous downtown stroll in Satines 1.6 and the interrupted one in Satines 1.9." Yel. as Oliensis has shown, the satirist's response to fame and prestige is more enigmatic than that: a dominant theme in this book of poems is Horace's negotiation of his rise to fame and prestige on the one hand. and his condemnation of ambition and social climbing on the other.' The satirist achieves his own social ascent by decrying those who strive for social ascent. The resultant strain between these two positions pervades this book of poems and is, I believe. played out in Rome s cityscape.

1. See Salmon 1952. Castaznoli 1952. and Schmituer 1994

2. See Dyson and Prior 1995. These authon compare Horace sotenc city wh Martial's, and find Horace less detailed about urban location than the latier wionu

3. Dyson and Prior 1995: 261-63

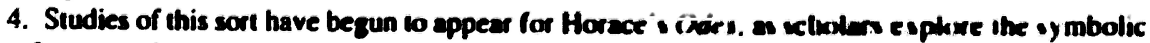
value of topoegraphy. monuments, and spatial relationahips in them See pankularly Prarcy 1977. Hardie 1993. and Leach 1997. who have each studied differeas apects of the iymbolic value of space. monuments. and copozraphy in Horace; Odes. Simulerly. Zetuel 1982 evamines how the appearance of Meecenas name in Horace's poetry marks not coly a hadoncal cifcumvance las part of the poems' creative and performative context). but alwo a thetorkal wretery (as pan of the poems" content). Meccenas' name-a nexus of images of rank. Uatus. (rtembhup. prow er. morality. and an-contributes to Horece's exploretion of these themen.

5. Both archecologists and philologiats generally except that Macenas renovatumo of the area predate these poems. See. Ior example. Bell 1998. Haubet 1990. Fraenhel |1957] 1964 123 n.2. Rudd [1966] 1982: 70. and Richlin [1983] 1992: 177

6. Jeeger 1990: $92-102$.

7. See Oliensis 1998: 17-63. 
In Satire's 1.9 Horace sketches a contrast between the city center, where he cannot escape the conversation of an ambitious would-be poet. and the garden home of Maccenas, where competition and ambition do not taint relationships or speech." In this prein and elsewhere in the boxk. however. Horace demonstrates a partiality for the city center. Why would he prefer it, if he can avoid bad behavior like the aspirant s by remaining in the gardens? In short. Horace's presentation of Maecenas' gardens as a place free from the vices of the city denies them material appropriate (o) satiric poetry. Horace needs the city center to feed his satire. for satire. based as it is on human folly. is out of place in the gardens as he presents them. The gardens (and what they represent) thus place Horace in a position that is a moral and acsthetic problem. Their specter haunts his walk in Sarines 1.9 just as much as does the aspirant.

When read together with Satires 1.8. the latent politics of the gardens and the paradox of Horace's position in them are even more haunting. In Satires 1.8, Priapus. lowly guardian of that portion of the ganden that used to be a cemetery, cannot speak effectively in the presence of the witches who threaten his domain, hut can only fart-a substitute reaction for the invective this god would normally employ. Priapus' invective speech is stifled, much as Horace's own satiric voice is stifled in the presence of Maecenas. The tale of Priapus locates this incapacity for speech firmly in Maccenas gardens. a situation that embodies the tension hetween the satirist s poetry and his patron. The satirist cannot turn his satiric eye onto the greater man on whom he depends.

Sarires 1.9. which draws on Catullus 10 and perhaps the work of Lucilius as well." places Horace on the Sacra Via. accosted by an aspirant to the circle of Maccenas." The narrative-and Horace's embarrassment-unfold along his

8 II in generally ascumed that the dowmes about which Horace speaks in 1.9 .49 and the horti in I 87 buh refer Io Maecena' complex on the Fequiline. his only known Roman home. Horace in Salires 2 h referv lo Macuenas garden home as atras Eisquilias (2.6.32-33). and he refers in the

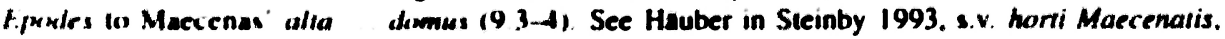
and Byrne loys is

9 The echo of (alullus 10 is generally accepted. See Fraenkel [1957] 1966: 114-15. Rudd ||$W 6$ | 1982 74 with nowe 38. Quinn 120-21. and Freudenburg 1993: 210. A Lucilian prototype is in grcater dispulc Since Fiske 1920, 3,30-36 firs argued for a specific Lucilian model for Sarines 1 Y hace in Warmington 254-98 = Marx 11.38 and Warmington 267-68 = Marx 231. the strongest arguments for a I.ccilian prototype have come from Andenon 1982: 84- 102, who demonstrates how Horace " Iranslation of Ilicad 20 4.3 into Latin and his contextualization of this Homeric passage in a prem filled with martial imagery irump l.ucilius' unintegrated, untranslated quotation. For a more cautious vien, however, see fraenkel [1957] 1966: 1 12-13. who believes that, while the later satirist cchics his literary ancestor in particular turns of phrane. we need not assume a specific Lucilian prem analoginus in Satırrs 19 Rudd 196198 rejects the prototype completely: "The Lucilian bore whuld be forginten as wmm an pinsible." His strongest contention. in my view, is that the fragments if l.ucilius on which the idea of the prototype is based are impossible to reconstruct with certainty.

10 Horace' interlocutor has heen called many names. each implying an interpretation of the whole porem On the mose descriptive side. he is called a chatterer / Schwitzer (from Horace is own karrulus. 1 9 3., and Rarrins. 19 13. by Knoche 1971). quadam (by Schmitzer 1994, from 1.9.3). and hore (Rudd $|\times|$ | hut see helow: and. following him. Fraenkel (1957) 1966). The scholars 
path through the Forum until Horace, no longer able to listen without comment, offers an impassioned correction to the aspirant's misperceptions about the actual workings of his great friend's society. This vignette can be understood not as an autobiographical report, but as an invented scenario through which Horace can praise Maecenas and his circle. ${ }^{11}$ The portrait Horace offers of life in Maecenas' circle quite contrasts with the aspirant's own demonstrated behavior in the same poem. First, the aspirant engages in the sort of ambition that Horace has elsewhere disdained (Satires 1.1, 1.6)--ambition lacking among Maecenas' friends (domus ... nec magis his aliena malis, 1.9.50-51, where the Latin word his points directly to the aspirant). ${ }^{12}$ Moreover, this interlocutor makes Horace prey to his aspirations. No such breach of decorum is possible in Maecenas' circle, for there each one knows his own place (est locus uni / cuique suus, 1.9.51-52). At the same time, Horace's new acquaintance espouses a poetic style disparaged by Horace throughout the Satires, and out of place among the members of Maecenas' circle of poets. For example, Horace's would-be friend touts himself as doctus (1.9.7: "noris nos" inquit; "docti sumus"), a trait that Horace says does not matter among Maecenas' coterie (1.9.50-51: " nil mi officit" inquam / "ditior hic aut est quia doctior").

The disparity between the aspirant's moral and poetic behavior and the reported norms of poets in Maecenas' circle has been long recognized. ${ }^{13}$ What remains unexplored, however, is how this disparity is underlined by topographical distinctions in this poem and elsewhere in the first book. Throughout this poem Horace and the aspirant equate the circle of Maecenas with his Esquiline domus. The contrasting behavior of members of Maecenas' circle and the aspirant is superimposed onto a similar contrast between the dignified suburban home of Maecenas on the one hand and discourteous downtown on the other. ${ }^{14}$ At the same time Horace constructs this perceptible distinction between desirable social and poetic values and undesirable ones, between distinguished places and common ones, as a liability to his satiric poetry. Having achieved a high status as a member

who use such terms see the poem more or less as one of Horace's literary nugae (1.9.2). For those who read the poem as a comment on social position and mobility in Rome, the character is called a Karrierist (Latacz 1980), or a pest (Zetzel 1980, Henderson 1993 and, curiously, Rudd [1966] 1982). The naming of this character by commentators receives insightful treatment by Henderson 1993: 67 and n.11. I prefer Oliensis' one-time rendering "aspirant" (1998: 38) as a way to indicate the character's ambition but lighten the negative connotations carried in "Karrierist" and "pest."

11. See, for example, Oliensis 1998: 36-39. The disrupted word order and broken clauses, she argues, lend the description a genuine air. See Fraenkel [1957] 1966: 116 for occurrences of this same impassioned style of speech in Satires 1.5.41ff. and Odes 4.2.37ff.

12. The text used throughout this paper is Wickham's [1901] 1991 edition for Oxford. All translations are my own.

13. See, for example, Rudd [1966] 1982: 83.

14. I use the term "suburban" here in its broader sense, meaning "close to the city," rather than the narrow sense, "within the city walls." Maecenas' garden complex seems to have straddled the city walls; while the old cemetery lay outside the walls, the Auditorium Maecenatis lay just inside. See Häuber 1990: 16-17 and passim, and Bell 1998: 299 for maps of the garden complex. 
of Maecenas' retinue, Horace belongs to the former, higher group, and his poetic genre partakes of the latter, lower one.

Let us examine the convergence of place, morality, and poetry in this poem. Responding to the aspirant's questions and assumptions, Horace describes life as part of Maecenas' circle in terms of the nobleman's home (domus):

"non isto vivimus illic

quo tu rere modo; domus hac nec purior ulla est

nec magis his aliena malis; nil mi officit" inquam

"ditior hic aut est quia doctior; est locus uni

cuique suus."

"We don't live there in the way you think; no house is purer than this one, nor more free from these evils; it doesn't bother me at all," I say, "if this man is richer or more learned; each one person has his own place."

This equation of poetic society and specific place is possible via the Roman concept of artistic patronage, a relationship styled by the Romans as amicitia. ${ }^{15}$ Instead of specific material remuneration for artistic production, poets in the retinue of a rich friend might hope for less formal recognition for their art. White describes many of these less formal returns, among which are dinners at the home of the rich friend and access to a larger and more sophisticated audience. ${ }^{16}$ The focal point of this relationship and its rewards is the house of the patron, and there is much supporting evidence for this in the fact that artists seem regularly to have waited upon their patron at his home in the mornings. ${ }^{17}$ One scholar even suggests that Horace, Vergil, and Propertius - all members of Maecenas' circle-lived on the Esquiline, in or near Maecenas' gardens, in which the Etruscan nobleman's own domus lay. ${ }^{18}$

15. White 1978 and 1993, but for a more skeptical view see Henderson 1993: 80 with notes 75-76, following Griffin 1984 and Wallace-Hadrill 1989: 1-13.

16. White 1978: 84-92, and see especially the list of more tangible rewards on 90-92.

17. White 1993: 4-5 with notes 2-3: "The great man's house (domus) therefore came to symbolize the very spirit of intercourse with the rich and powerful." Wallace-Hadrill 1989: 6364 discusses the importance of the home of the patron in Roman ideology of the broader concept (i.e. political, legal, and poetic) of patronage. While White 1993: 36-38 cautions against the metaphor of the "circle," explaining that it implies a boundary and a center and is therefore too formal and rigid a structure to describe the fluid relationships in a poetic coterie such as Maecenas', nevertheless the notion of a cluster of associates around a great man is difficult to avoid in the poetry itself. White elsewhere acknowledges, for example, that one of the concerns of Horace's Satires $(1.7,1.8$, and 1.9) is to present to outsiders a view of the artistic friendship "from a vantage point inside the group. The relationships within the group either come in for comment as other persons impinge on it, or they provide an implicit reference point for appreciating what is noticed about outsiders" (White 1993: 86).

18. Häuber 1990: 65 with note 184 gathers literary indicia of the poets' residence in the Esquiline estate. She places the poets' houses and Maecenas' in proximity to the Diaeta Apollonis (100), a building evocative, she argues (92-93), of the famous Museion, by which Maecenas styled his gardens as the Roman Alexandria. This artistic atmosphere of the Diaeta must have been enhanced 
Satires 1.9 constructs Maecenas' gardens as a place apart. Many readers have noted that the first person verb vivimus in 1.9.48, followed in the next line by $t u$, establishes a grammatical distinction between Horace and the aspirant that underlines Horace's emotional distance from him. ${ }^{19}$ Likewise Horace highlights the physical separation of Maecenas' gardens from his current location on the Sacra Via. The emotional distance Horace expresses with vivimus ...tu resides also in the physical distance implied in illic (1.9.48), "we live there." The poet's outburst is a direct response to the aspirant's bald suggestion that Horace exchange favors for friendship. His use of his in 1.9 .50 points a strong accusatory finger at his interlocutor, setting a contrast between the polite and respectful behavior of Maecenas' friends and the competitive intrusive behavior the aspirant has just suggested. ${ }^{20} \mathrm{His}$ also resonates with the spatial indicator illic from 1.48: these (his; sc. values you demonstrate here in the Forum) are not like it is there (illic; sc. in Maecenas' home). The use of hac in 1.9.49 is telling in this context. Though the poet is physically far from Maecenas' home, he has so internalized the values of Maecenas' home that he carries it with him: he cannot but be polite to his persistent interlocutor. Where we might expect satiric invective against this caricature, we find instead only restraint. $^{21}$

Horace arranges contrasting moral and poetic values along this topographical contrast. For example, topography aligns with morality in the word purus (domus hac nec purior ulla est, 1.9.49). No house is purer than Maecenas'. What exactly does this mean? The answer is partly to be found in Satires 1.6, in another passage that draws together poetry, ambition, social ascent, Maecenas' circle, and locale:

magnum hoc ego duco

quod placui tibi, qui turpi secernis honestum, non patre praeclaro sed vita et pectore puro. atqui si vitiis mediocribus ac mea paucis mendosa est natura alioquin recta, velut si egregio inspersos reprehendas corpore naevos; si neque avaritiam neque sordis nec mala lustra obiciet vere quisquam mihi, purus et insons

by the Greek statuary located in the garden. Bell sees the influx of Greek funerary sculpture to this area in the context of Maecenas' transformation of a bleak public cemetery into a private pleasure garden, evocative of the famous Kerameikos cemetery at Athens. The sculpture, Bell 1998 notes (308), would have been the best way to achieve a recherché effect.

19. See, for example, Rudd [1966] 1982: 77. The separation is maintained by Horace's use of impersonal verbs (ventum erat, 1.9.35). The first person plural consistimus in 1.9 .62 includes the poet and Aristius Fuscus, but not the aspirant.

20. Latacz 1980: 17-18, though he does not emphasize the word his, nevertheless emphasizes the discrepancy between the corrupt world of the Karrierist and the ideal world of Maecenas' circle.

21. Most commentators see Horace's restraint as the source of this poem's humor, but for a different view see Henderson 1993. 
(ut me collaudem) si et vivo carus amicis; causa fuit pater his....

I consider it a great thing, the fact that I was pleasing to you, who can tell an honest man from a scoundrel, not because he has a famous father but from (his) life and (his) pure heart. But if my nature is faulty, endowed with a few mediocre vices but otherwise proper, as, for example, you might censure freckles sprinkled on a lovely body, or if someone is able to cast on me justly neither charges of avarice nor of cheapness nor of loitering in bad places, and if I live my life pure and uncorrupted (if I may praise myself thus), and if also I live dear to my friends, my father was the reason for these things.

Here Horace defends his role as Maecenas' protégé. Though others envy his ascent up the ladder of prestige, the reason for his ascent, he asserts, was not ambition but purity, which Horace attributes to his father's care. His father also ensured Horace would spend his time in suitable, not corrupt, places (nec mala lustra, 1.6.68). Maecenas' home-purus in 1.9.49-is one such suitable place. Through the word purus, Maecenas' house itself becomes a physical locus for the sort of moral excellence that guarantees social ascent without ambition-an excellence the aspirant, trying to climb without having demonstrated his merit, apparently lacks. The topographical exclusion of ambition from Maecenas' circle and home is reinforced by a brief passage, again in Satires 1.6, describing Maecenas:

... ita te quoque amicum, praesertim cautum dignos adsumere, prava ambitione procul.

[they could not envy] you thus as my friend, since you are especially careful to take up those worthy, far from immoral ambition.

Either Maecenas lacks ambition, or those he takes up lack it-the Latin is ambiguous. Likewise, it is with ambition set aside that Horace gives the roster of his friends in Satires 1.10:

Plotius et Varius, Maecenas Vergiliusque, Valgius, et probet haec Octavius, optimus atque Fuscus, et haec utinam Viscorum laudet uterque! ambitione relegata te dicere possum, Pollio, te, Messalla, tuo cum fratre, simulque vos, Bibule et Servi, simul his te, candide Furni, compluris alios, doctos ego quos et amicos prudens praetereo.... 
Let Plotius and Varius, Maecenas and Vergil, Valgius, yes, and let Octavius approve of these poems, and Fuscus too, that great man, and would that either of the Viscus brothers praise them! With ambition set aside I am able to speak of you, Pollio, and you, Messalla, along with your brother, and at the same time you both, Bibulus and Servius, and together with them you, splendid Furnius, and many others, learned men and friends whom I discreetly pass over.

Like procul in 1.6.52, relegata is first and foremost a spatial word. ${ }^{22}$ As Maecenas' circle is far from ambition, so too is his house.

The word purus in the Satires also refers to Horace's particular poetic style, which favors clean simple diction. In Satires 1.4, Horace mockingly voices the complaints of his poetic detractors, that simple words artfully arranged do not constitute poetry:

ergo

non satis est puris versum perscribere verbis, quem si dissolvas, quivis stomachetur eodem quo personatus pacto pater. his ego, quae nunc, olim quae scripsit Lucilius, eripias si tempora certa modosque, et quod prius ordine verbum est posterius facias, praeponens ultima primis, non, ut si solvas "postquam Discordia taetra Belli ferratos postis postasque refregit," invenias etiam disiecti membra poetae.

Therefore it is not enough to write verse with simple diction, which, if you shuffle it all up, any father you like could use to gripe in the same way as a father being portrayed in a play. From these things that I write now, and that Lucilius wrote long ago, if you should take away the structured rhythms and the measures, and if you should place later a word that was earlier in order, putting the last words in front of the first, you would not find even the limbs of a dismembered poet, as you would if you were to dissolve "After doleful Discord broke the bolted bolts and portals of War."

Severe critics who demand Ennian-style diction, in other words, find Horace's purus verses to be inadequate as poetry. ${ }^{23}$ Maecenas' house, purior than any other, is therefore the most appropriate setting for Horace's pedestrian poetic

22. Of course in both these passages the alleged lack of ambition is ironically contradicted by the patent ambition demonstrated in the writing of the words. See below. For a non-topographical criticism of ambition, describing Horace's own day, see 1.6.128-29 (haec est/vita solutorum misera ambitione gravique).

23. Freudenburg 1993: 145-50, by examining contemporary rhetorical and poetic theory, amply demonstrates that this passage frames the accusations of a certain branch of Horace's detractorsnamely, conservative Stoic theorists of language. Horace's very artful word order in this passage trumps his detractors. 
production. While purus refers directly to the aesthetic choice of straightforward diction in 1.4.54, it also evokes the traditions of Callimachean poetic values that recur throughout the Satires. ${ }^{24}$

At 1.1.59-60, a passage about greed, Horace disdains the torrential river Aufidus and urges the reader to drink from the river unsullied with mud. The passage recalls Callimachus' Hymn to Apollo, in which the god urges the poet to avoid the muddy Euphrates in favor of the pure droplets of the spring of the goddess Deo (108-12). In 1.4.11 and again at 1.10.50-51, Horace describes Lucilius' style as muddy (lutulentus)-i.e., unrefined in the Callimachean sense. Indeed at the close of Satires $1.9(=1.9 .78)$, Apollo, patron god of Callimachean poetic values (purus poetry), appears himself to protect Horace from his poetic interloper. ${ }^{25}$ These references and others combine Callimachean polemics with more contemporary rhetorical theory to reveal Horace's bias for simple diction, artfully arranged-both aspects resonant with the word purus. ${ }^{26}$

The word purus, then, has double resonance: it combines moral and aesthetic concerns. As the adjective applied to Maecenas' house, it blends these concerns with topography in a way that maps certain behavior onto a specific place. The aspirant also uses location as a metaphor for life in the famous circle of poets. Consider the exchange that follows Horace's description of life in Maecenas' home:

"magnum narras, vix credibile." "atqui sic habet." "accendis, quare cupiam magis illi proximus esse." "velis tantummodo, quae tua virtus, expugnabis; et est qui vinci possit, eoque difficilis aditus primos habet." "haud mihi deero: muneribus servos corrumpam; non hodie si exclusus fuero, desistam; tempora quaeram, occurram in triviis; deducam. nil sine magno vita labore dedit mortalibus."

24. See, for example, Cody 1976 and Scodel 1987

25. There is much debate about Apollo's complex role in 1.9.78. Though most scholars accept Porphyrio's assertion that Horace here translates Lucilius' Greek quotation of Homer Iliad 20.443, Apollo's other functions remain less clear. See Anderson 1982: 84-102 for a full discussion of this translation. I agree with Anderson that Apollo appears in this poem as a patron god of poetry rather than as an indication of a specific monument along Horace's route. For a topographical Apollo, see primarily Salmon 1952 and Schmitzer 1994. Salmon believed 1.9 .78 to be a reference to the Temple of Apollo Medicus in the Jewish Quarter, a detail that helps explain Iudaei in 1.9.70, but see Castagnoli 1952 on the chronological problems that arise from this interpretation, and Rudd [1966] 1982: 84 for an alternative explanation of Iudaei. Schmitzer saw an allusion to the Temple of Apollo Palatinus, an evocation that likens Horace's escape from his interlocutor to Octavian's from Sextus Pompeius. The problems of dating are even more difficult to dismiss in this case than in Salmon's interpretation.

26. Freudenburg 1993: $157-59$ and 188-90. At 1.7.26-27, the muddy stream combines Callimachus' Euphrates with more recent criticism of the excesses of the Asiatic style of Satires 1.7's Persius, on which see Freudenburg 1993: 208. 
"You tell a great tale-scarcely believable!" "And yet that's how it is." "You excite me, so that I wish all the more to be close to him." "Simply wish it, which is your strong point, and you will win out; and he is a man who is able to be won, and therefore he keeps his initial points of approach difficult." "I shall hardly stay away: I shall break his slaves with bribes; if I am shut out today, I shall not give up; I shall await opportunities, I shall ambush him at the crossroads; I shall attend him. Life has given nothing to mortals without great labor."

The aspirant's words proximus and exclusus suggest spatial as well as social relationships or, rather, spatial relationships as social relationships. The martial language and imagery in this passage, which present Maecenas' domus as a fortress to be stormed, reinforces the physical segregation of the aspirant from Maecenas. ${ }^{27}$ These few lines reinforce Maecenas' domus as a place apart from the city center, where Horace's unwelcome companion spends his time.

The aspirant's demonstrated behavior in this poem is inappropriate to the moral and aesthetic timbre of Maecenas' gardens. His conduct in Horace's company is unacceptably rude. He interrupts Horace's privacy, both physical and mental (1.9.1-4). He refuses to take hints of Horace's desire to escape (1.9.811 ), even though he recognizes that desire (1.9.14-16). Worst of all, he asks to be introduced to Maecenas, indicating that Horace is only a means to a greater end (1.9.43-48). As Rudd says, "There is in fact no word which will include the garrulity, the conceit, the persistence, and the crass insensitivity of the social climber." ${ }^{28}$ Indeed, as mentioned above, Horace, in his passionate rejection of the aspirant's notion of life in Maecenas' circle, points an accusing finger at this trespasser's moral behavior with his malis (1.9.50). ${ }^{29}$ Even after hearing this "correction," the aspirant ignores his own moral inadequacy. For example, whereas Horace left Maecenas alone for nine months (abeo et revocas nono post mense, 1.6.61), this man will never let Maecenas alone (haud mihi deero, 1.9.56), just as he does not let Horace alone (usque tenebo; persequar hinc quo nunc iter est tibi, 1.9.15-16). He completely disregards Horace's hint about propriety in Maecenas' home (est locus uni / cuique suus, 1.9.51-52).

The aspirant is also aesthetically ill-suited for life in Maecenas' garden-circle. He haplessly boasts about his own prolixity:

"si bene novi non Viscum pluris amicum, non Varium facies: nam qui me scribere pluris aut citius possit versus? quis membra movere

27. Anderson 1982: 84-102 discusses how the martial metaphor in Satires 1.9 (played out through words such as expugnabis, vinci, aditus) fits into Horace's satiric revision of Lucilius. The metaphor is made richer by the fact that the aspirant "storms" Horace on the Sacra Via-Rome's triumphal route.

28. Rudd [1966] 1982: 74, and cf. Oliensis 1998: 37.

29. See above, p. 168 . 
mollius? invideat quod et Hermogenes ego canto."

"If I know myself well, you will not count Viscus, not Varius as more of a friend that you will find me: for who is able to write more verses or more quickly than I? Who is able to move his limbs more gracefully than I? Even Hermogenes would be envious, because I sing."

Horace finds hastily composed poetry sloppy. A disparaging description of Lucilius from Satires 1.4 fits the aspirant's self-proclaimed prolixity almost exactly:

nam fuit hoc vitiosus: in hora saepe ducentos, ut magnum, versus dictabat stans pede in uno: cum flueret lutulentus, erat quod tollere velles: garrulus atque piger scribendi ferre laborem, scribendi recte....

For he was blameworthy in this: in one hour he often used to dictate, as if it were something great, two hundred verses while standing on one foot: since his flow was muddy, there was material you would wish to take out: he was wordy, and too sluggish to bear the labor of writing, that is, of writing well....

Some of Lucilius' poetic descendants, too, are carelessly discursive:

sunt quibus in satira videar nimis acer et ultra legem tendere opus; sine nervis altera quidquid composui pars esse putat, similisque meorum mille die versus deduci posse.

There are those to whom I seem too harsh in my satire, and to whom I seem to stretch the undertaking beyond its jurisdiction. The other faction thinks whatever I write lacks guts, and that a thousand lines a day like mine can be spun out.

Here Horace presents the opinions of the two primary camps of his critics: ultrarefined Neoterics, in whose opinion Horace's verses are too rugged (2.1.1-2), and rugged Stoic extremists, who find Horace's satire too Neoteric (2.1.2-4).$^{30}$ Each group had laid claim to Lucilius as a model, and Horace apparently disappointed each. ${ }^{31}$ The aspirant falls into the former group, the Neoterics lampooned at 2.1.34 above, who spin out thousands of lines per day of polished but gutless poetry. The aspirant's self-proclaimed prolixity, along with his boast of graceful movement

30. Freudenburg 1990 and 1993: 163-84.

31. Freudenburg 1993: 173-84. 
(1.9.21-25, above) - a boast that suggests effeminacy and the prostitution of talent-aligns him with this group of neo-Lucilian Neoteric poets.

So too does his speech (cited above) of 1.9.56-60:

"haud mihi deero:

muneribus servos corrumpam; non, hodie si exclusus fuero, desistam; tempora quaeram; occurram in triviis; deducam. nil sine magno vita labore dedit mortalibus."

"I shall hardly stay away: I shall break his slaves with bribes; if I am shut out today, I shall not give up; I shall await opportunities; I shall ambush him at the crossroads; I shall attend him. Life has given nothing to mortals without great labor."

This rejoinder is rich with instances of bucolic diaeresis (four occurrences in as many lines), molossus (three: desistam, deducam, corrumpam), and masculine caesura-all features attractive to the Neoterics, here so densely packed within a few lines that the effect is strong. ${ }^{32}$ This stylized set piece builds to a gnomic statement and ends with a rousing archaic mortalibus, a word favored by Ennius and his contemporaries. ${ }^{33}$ Given the martial metaphor he uses to describe his entry into Maecenas' circle, the aspirant sounds like a neo-Ennian Neoteric poet, à la Furius Bibaculus. ${ }^{34}$

Indeed so self-conscious is he of his own poetic tastes that the aspirant packs his speech with Neoteric buzzwords. In the rejoinder above, he promises to seek out tempora, opportunities (1.9.58) - but also rhythms. ${ }^{35}$ He will escort (deducam,

32. Freudenburg 1996 identifies these elements as Neoteric in the speech of the Epicurean Catius in Satires 2.4. Nilsson 1952: $178 \mathrm{n} .2$ identifies the metrical monotony of the aspirant's speech. To him, this monotony reflects his persistence. Though Nilsson later (179) mentions that the aspirant's speech patterns seem the opposite of Catius' style insofar as they lack elision, he admits the sample is too small for statistical significance.

33. For the gnomic statement that puts the aspirant "on the plane of moral philosophy" (Courtney 1994: 5), see Tosi 1994: 750-51 (\#1685) and Otto 1890: 181 (\#891). The archaism mortalis appears in Naevius (apud Gellius 1.24.2), Accius (Warmington 536), Ennius (Skutsch 20, 366, and 574), and in old satiric contexts: Ennius Satires (Warmington 6), and Lucilius (Warmington $536=$ Marx 533). The aspirant's archaic language here is echoed by the Epode 2's Alfius, another urban character who romanticizes escape to the suburbs.

34. There may also be shades of the elegiac exclusus amator and the trope of militia amoris in the aspirant's speech-shades that would further complicate the aspirant's poetic dissimilarity to Horatian satire.

35. Given the metrical meaning of tempora in the Satires (see, for example, 2.1.17-19, a passage which also begins "haud mihi deero"), the aspirant's claim to seek them out (tempora quaeram, 1.9.58) in the context of his own metrically monotonous speech is humorously absurd. Aristius Fuscus' comment at 1.9.68-69 (memini bene, sed meliore / tempore dicam; I remember well, but I will tell you at a better time) gains in humor if the aspirant's words are read as poetic self-consciousness. 
1.9.59) the great man - and at the same time engage in refinement. ${ }^{36}$ Earlier in the poem, he reveals to Horace that he has buried (composui, 1.9.28) all his loved ones-or composed everything. ${ }^{37}$ These double-entendres, along with the metrical display in 1.9.56-60, cast the aspirant as an extremist, too narrowly confined for Horace's moderate tastes, and for Maecenas' circle.

Thus far we have explored how Maecenas' Esquiline home doubles as a metaphor for the moral behavior and poetic values Horace promotes in his Satires, and how Horace's interlocutor in Satires 1.9 fails to understand the moral and poetic attitudes associated with this place. The juxtaposition of gardens and city in this poem reinforces the metaphorical portrait of Maecenas' home, for where the Esquiline manifests good character, the urban center is crowded with the opposite. ${ }^{38}$ The aspirant's assault on Horace occurs in the very heart of the cityalong the Sacra Via - and Horace mentions other locations that fix the bothersome episode in Rome's center (ventum erat ad Vestae: 1.9.35; vicos, urbem laudaret: 1.9.13; cf. trans Tiberim longe cubat is 1.9.18). ${ }^{39}$ The contrast between Esquiline and Forum blurted out by Horace in response to his hanger-on has been noted above: there we don't behave the way you think $(1.9 .49$, sc. "and the way you behave here"). ${ }^{40}$

Inappropriate behavior is connected to the city center elsewhere in the Satires as well. In Satires 1.6, those whose political ambition sparks concern for the physical city open themselves up to the nuisances attendant upon ambition:

sic qui promittit civis, urbem sibi curae, imperium fore et Italiam, delubra deorum, quo patre sit natus, num ignota matre inhonestus, omnis mortalis curare et quaerere cogit.

And so he who promises that the citizens, that the city will be of concern to him, as well as Rome's sovereignty, and the shrines of the gods, he compels all mortals to take care and to seek to know from what father he was born, or whether he's a scoundrel from an unknown mother.

36. The word deducere appears in 2.1.4 (see above) and cf. 1.1.15 and 1.10.7. The locus classicus is Vergil Eclogue 6.4-5: pastorem, Tityre, pinguis/pascere oportet ovis, deductum dicere carmen (it is fitting, Tityrus, for a shepherd to fatten up his sheep, but to keep his song lithe).

37. For componere as a poetic word, see, for example, 2.1.3 (quidquid composui) and 1.4.8 (durus componere versus, harsh to compose verses). The aspirant's boast that he is not lazy (non sum piger, 1.9.19) may also fit into this category of double-entendre: Horace had complained at 1.4.12 about Lucilius' laziness: garrulus atque piger scribendi ferre laborem (wordy and sluggish to bear the labor of writing). Cf. labore (1.9.60) and labores (1.10.73).

38. Dyson and Prior 1995: 262 see Horace as an anti-urban persona because of his preference for the suburbs over the urbs.

39. The mention of the vicos could be general, but could have been inspired by the nearby Vicus Iugarius and Vicus Tuscus, two famous vici in the immediate vicinity. See above, note 25 , on the possibility of sic me servavit Apollo (1.9.78) as a topographical reference.

40. See above, p. 170. 
In stark contrast to the city-loving office-seeker, plagued by questions, Maecenas declines in the same poem to ask Horace about his family (1.6.58-64). Here too the city center, not Maecenas' ambition-free Esquiline residence, is the locus for ambition and invasive questions. ${ }^{41}$ Horace and Maecenas do not participate in this urban phenomenon, despite the fact that higher political office became a real possibility for Horace through his friendship with Maecenas. ${ }^{42}$ Horace sums up this dynamic of the city center later in this same poem when he describes it as fallax (fallacem circum, vespertinumque pererro / saepe Forum, 1.6.113-14). The word fallax combines danger with deceit. ${ }^{43}$ The tainted city center of Satires 1.6 helps the reader to understand the downtown setting of Horace's unfortunate encounter with the aspirant in Satires 1.9. Indeed Horace seems to underline the contrast between downtown and suburb in Satires 1.9 when he mentions an intended visit to a friend across the Tiber, near the Gardens of Caesar:

quendam volo visere non tibi notum:

trans Tiberim longe cubat is, prope Caesaris hortos.

I wish to visit a certain man, not known to you: he lives far across the Tiber, near the Gardens of Caesar.

The poet invents this intended visit to try to ditch his interlocutor (he has already told us in 1.9.1 that he is out for a casual stroll downtown, not on a personal errand). More to my point, he invents another rus-in-urbe setting, like Maecenas' gardens, in which the aspirant would be out of place. ${ }^{44}$ Horace emphasizes that this other "garden friend" is unknown to his follower, thus excluding the aspirant from the elite crowd once again.

Horace has, therefore, created a conceptual city in which Maecenas' garden home, the poets associated with it, and speech in general are morally and aesthetically aligned under the rubric "pure." It is a place and company marked by absence of social and poetic competition and by rigor of poetic practice (domus hac nec purior ulla est nec magis his aliena malis, 1.9.48-49), and by awareness of and respect for others (locus uni cuique suus, 1.9.52). ${ }^{45}$ These qualities inscribe Maecenas' garden complex into the Epicurean tradition. The interconnection of

41. In a passage in the later Satires 2.6 , to be discussed below, Horace describes invasive rumors leaking out from the Rostra, the symbolic locus of speech in the city center (2.6.50).

42. See Armstrong 1986. Indeed, Satires 1.6 is Horace's defense of his already-prominent social position as eques et scriba, and an abnegation of excessive ambition on his own part and that of Maecenas.

43. OLD s.v. fallax, entries 1 and 2.

44. Caesar's gardens were public and therefore presumably open to all visitors, aspirant included. Nevertheless, Horace finds a way to exclude him by combining his (lack of) social ties with a suburban garden setting.

45. According to Tosi 1994: 511 (\#1119), this maxim embodies a fundamental precept of Roman law, and therefore connotes respect for others. Otto 1890: 337 (\#1726), on the other hand, leaves open the possibility of irony in this phrase. 
res (content) and verba (style), such as that which operates in Horace's use of the word purus, was of paramount importance in first-century Epicurean theory. Lucretius and Philodemus both concern themselves with this provocative pairing. ${ }^{46}$ Indeed, the poetry of the latter philosopher figures heavily as a Horatian satiric intertext. ${ }^{47}$ For the purposes of this paper, I would like to draw attention to the fact that Horace adds Roman location to this combination of res and verba, just as he adds the word locus to the idiom cuique suus. In the poetic and moral qualities mentioned above, Maecenas' garden home differs from the city center, where Horace's aspirant-friend advances his claim with manifest ambition and without regard for Horace's own poetic standards. In the city center-fallax-it is just so: one finds social ambition and poor poetry.

However, even as Horace sketches for the reader this "charming portrait of life in the charmed circle of Maecenas," ${ }^{48}$ he simultaneously casts doubts on its accuracy. For one thing, however pure and laudable life in Maecenas' circle might be, Horace expresses more than once a partiality for Rome's "seedy" downtown. Moreover, many careful readers have noted that Horace's behavior-both in this poem and elsewhere, as we shall see-is not exemplary of the way of life he describes among Maecenas' company. ${ }^{49}$ These nuances suggest that the map of moral, social, and poetic values is more complex than the surface structure we have examined thus far. Rather, the counter-indications Horace offers against 1.9.48-52 expose an inherent tension between Horace's production of satiric poetry and his place among the elite of Maecenas' circle. In short, satire is typically not an elite genre, and Horace now socializes in elite circles.

The most obvious point of tension is Horace's fondness for downtown. It is his custom to stroll in the Forum:

Ibam forte via Sacra, sicut meus est mos, nescio quid meditans nugarum, totus in illis.

I was walking along the Sacra Via by chance, as is my custom, thinking about some trifles or other, entirely absorbed in these.

Nugae and meditans conjure images of the poet at work..$^{50}$ We can conclude from these words that Horace's downtown strolls were somehow conducive to his poetic

46. Oberhelman and Armstrong 1994: 246 and passim.

47. See Oberhelman and Armstrong 1994 and Freudenburg 1993: 139-4.5 for the influence of Philodemus' theory on Horatian satire. For a study of the operation of res and verba together in Satires 1.7, see Schlegel 1999.

48. Zetzel 1980: 71 .

49. Among these are Freudenburg 1993: 208, Henderson 1993: 82-84, and Oliensis 1998: 36; the latter's arguments on Satires 1 generally see Horace defending himself against unstated accusations of his own social climbing.

50. Catullus 1.4 enshrined nugae as poetic tidbits, whereas meditari enters the Roman diction of poetic composition with Vergil's Eclogue 1.2. 
inspiration. ${ }^{51}$ The same connection between city center and poetic composition as complementary parts of Horace's day is found in the famous description of Horace's lifestyle at the end of Satires 1.6:

quacumque libido est,
incedo solus; percontor quanti holus ac far;
fallacem Circum vespertinumque pererro
saepe Forum....
ad quartam iaceo, post hac vagor, aut ego lecto
aut scripto quod me tacitum iuvet...
ast ubi me fessum sol acrior ire lavatum
admonuit, fugio Campum, lusumque trigonem.

$$
\text { (1.6.111-14, 122-23, 125-26) }
$$

Wherever it is my desire, I go there alone; I check out the price of greens and grain; I wander around the deceitful Circus, and often the Forum in the evenings.... I lie in bed until mid-morning, after that I wander around, or I read or write what pleases me in my leisure.... But when the sun climbing higher warns me, worn out, to go bathe, I flee the Campus, and the game of Three-throw.

In this passage too, Horace's writings-whatever pleases him (quod me tacitum iuvet, 1.6.123; cf. nescio quid, 1.9.2)-are connected to his wanderings in the city. His day is divided between wandering in the city and writing or reading.

A third passage referring to the process of poetic composition closely follows on the heels of mention of the urban center (a porticus, in this case):

neque enim, cum lectulus aut me porticus excepit, desum mihi: "rectius hoc est: hoc faciens vivam melius: sic dulcis amicis occuram: hoc quidam non belle; numquid ego illi imprudens olim faciam simile?" haec ego mecum compressis agito labris; ubi quid datur oti illudo chartis.

For I am not absent minded, when either my bed or the promenade has received me: "This is more proper." "Doing this, may I live better." "Thus dear to my friends may I run into them." "This man did not do this rightly. Would I ever act foolishly, like that one?" These things I mull over to myself with pursed lips; when a little bit of leisure is granted to me, I play around in my writing books.

51. It is interesting that the poetry Horace contemplates in the city center is Neoteric in style, indicating his adherence to the principle of variatio. Not all Neoterics are bad poets from the satirist's point of view, only the excessively dogmatic ones. See Freudenburg 1996: 205 and 1993: 181-84. 
The alternative of lectulus ... aut porticus in 1.4 .133 suggests "at home ... or out and about"; occurram in 1.4.136 reinforces the image of Horace in the city, and looks forward to Horace's meetings with the aspirant (1.9.3, accurrit) and Aristius Fuscus $(1.9 .61$, occurrit) on the Sacra Via in Satires 1.9 . Neither the city nor the mention of poetic composition appears in the model for this passage, Terence's Adelphoe $413-20 .{ }^{52}$ Horace adds the city center and his poetic composition to this comic description of how to learn from others' mistakes.

Observation of others' mistakes provides the key to Horace's predilection for Rome's urban center. Horace's hours downtown provide not only negative examples of behavior by which to refine his own character, but also, more importantly, they provide food for his satire. His daily perambulations in the Forum and the Circus bring him into contact with examples of all sorts of human folly: in the city Horace can "encounter social truth." ${ }^{3}$ The aspirant's dogged downtown siege in Satires 1.9 and the bothersome questions put to the urbanminded politician in Satires 1.6 are both results of the vice of ambition, one of the key targets of Horace's satiric attacks. Like Socrates of Plato's Phaedrus, Horace requires the city as a subject: "Forgive me, my dear friend, for I am a lover of learning. You see, the country places and the trees teach me nothing, but people in the city do." 54

This explains Horace's simultaneous criticism of and attraction to the city center: while he criticizes the faults he finds downtown, he is nevertheless drawn to them because of their satiric potential. The generic ancestors of Horace's satire-Greek and Roman comedy, iambic poetry, Cynic moralizing, and Lucilian satire-all select humanity's faults as their focus, leveling everyone to a common low denominator. ${ }^{55}$ The poet is not exempt from this leveling tendency: "Satire satirizes the satirist and satirizes the genre of Satire. Self-mockery is its mask and mark." 56 Thus arise contradictions in the poet's presentation of himself. While he ridicules the aspirant as an intrusive pest in Satires 1.9, the poet's self-portrait in Satires 1.1, 1.3, and 1.5 does not fall far short of similar behavior. In Satires 1.1, Horace pesters Maecenas just as he is pestered in Satires 1.9.57 In 1.3.63-65, Horace disturbs Maecenas' peace with his own chatter, and Satires 1.5's traveling

52. For Horace's use of Terence in this poem, see Leach 1971 and Freudenburg 1993: 27-52, especially 33-39.

53. Henderson 1993: 80. Henderson here likens the nighttime Forum to seedy Soho after dark. Henderson in this article, Dyson and Prior, and Jaeger point out that Horace's city is a city of people, not monuments; apart from Maecenas' new Esquiline gardens, he is curiously silent on Octavian's urban projects of the thirties, but cf. Kennedy 1992 on the effects of such silence.

54. Plato Phaedrus 230D. I owe this observation to West 1991: 74 who brought it to bear on the country-city contraposition of Satires $2.6-$ a dynamic not unrelated to the one I am arguing for in Satires 1 between the city center and Maecenas' garden complex on the outskirts.

55. Freudenburg 1993: 211-22. He finds Bakhtin's concept of the carnival a useful model in exploring this dimension of satire.

56. Henderson 1993: 69.

57. Zetzel 1980: 68, whose study of the contradictions unfolding with Horace's satiric persona is a keystone for the later studies mentioned in these pages, calls this pestering "button-holing." 
poet borders on the scurra. ${ }^{58}$ These poems liken Horace to the aspirant in Satires 1.9 in a way that reveals the paradox of his position at Maecenas' court: "The satirist climbs the social ladder by poking fun at social climbers." ${ }^{59}$ Horace faces this paradox face-front, and in so doing, satirizes himself and his own position. In order to mediate the accusation of hypocrisy that arises in the fiction of the poetry, at least, Horace emphasizes at every turn his modest background; while Horace's satire is his ticket into Maecenas' company, it is also "a leash binding him to and reminding him of his own humble beginnings." 60 He participates at Maecenas' domus in spite of his satire. Yet he participates in Maecenas'domus because of his satire.

The convergence of "because of" and "in spite of" that forms the dominant tension in Book 1 confounds the polarity of Maecenas' Esquiline house and Rome's city center that stands at the core of Satires 1.9 . While the aspirant seeks introduction on the hill, Horace seizes opportunities to retire from it. Horace prefers the fallacem Circum vespertinumque Forum (1.6.113-14) precisely in order to distance himself from Maecenas' house, to observe and to associate with the low-life of the city, to re-satirize himself. However, because of his new status, he finds himself ill at ease there as well, singled out from the crowd by the aspirant because of his access to a higher order. As far as can be known, the Lucilian prototype for Satires 1.9 presents a very different picture. ${ }^{61}$ In Lucilius' fragments, the poet watches while an aspirant approaches the patron Scipio himself. ${ }^{62}$ As the poet does not play an intermediary role in that scenario, attention does not focus on the role and status of the poet as it does in Horace's version. Horace expands on his Catullan prototype as well. In Catullus 10, while the status of the poet with respect to a patron is an issue, topography is not. ${ }^{63}$

In Satires 1.9, on the other hand, Horace represents himself as caught between the common man and the great man, metaphorically and physically. The poet's propensity for the city expresses in topographical terms the incongruity of his situation as part of Maecenas' domus with his chosen medium of satire. His satiric poetry is at odds with his access to Maecenas' domus, for his poetry dislocates him in the gardens, and his status dislocates him downtown. Horace's satiric poetry is also at odds with his deference to his patron: "One burden of ... the entire collection is to demonstrate that Horace's satiric eye, so sharp to see the failings of the man in the crowd, succumbs to a respectful blindness when

58. Freudenburg 1993: 203-207.

59. Oliensis 1998: 18.

60. Oliensis 1998: 25 .

61. Some scholars have expressed doubt about a Lucilian prototype for Satires 1.9. See above, note 9 , for these views.

62. Warmington $254-58=$ Marx 1138 and Warmington 267-68 = Marx 231.

63. See Skinner 1989 for the hierarchies of gender and poetic amicitia in Catullus 10. The poem touches on Roman places; the Forum Romanum is Catullus' starting point (10.1-2), and it focalizes the tension between otium and negotium in the poem. The poet's patron, however, is not written into the cityscape as is Maecenas in the Satires. 
confronted with the great man who picked Horace out of it," says Oliensis, who traces the prudent silence that runs throughout Book $1 .{ }^{64}$ In Satires 1.4 Horace demonstrates that he is the sort of good man he described in 1.3.73-75, who overlooks the foibles of his friends. Horace's deference is especially apparent in Satires 1.5, the famous journey to Brundisium, in which short-sightedness literally prevents Horace from disclosing Maecenas' secrets:

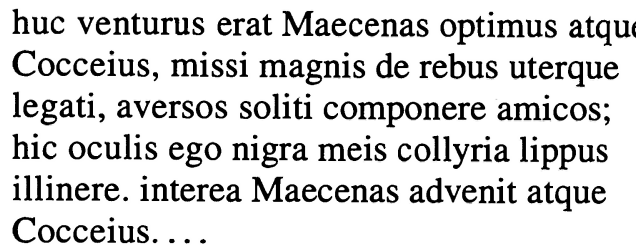

Excellent Maecenas was about to come here, along with Cocceius, ambassadors each sent about great affairs, men accustomed to patch up broken friendships; here, bleary-eyed, I smear my eyes with black ointment. Meanwhile, Maecenas arrives along with Cocceius....

Horace literally and figuratively darkens the eye that would see Maecenas and, in this poem, reveals nothing else about the great man. The poem is the very mark of discretion, as the poet transforms all the possible sources of anxiety about this important embassy into harmless personal difficulties. The only war waged is on Horace's stomach, for example (1.5.7-8), and the only frustrated hopes are Horace's hopes for an evening tryst (1.5.82-85). ${ }^{65}$ Such discretion quietly does the work of the new order, by normalizing the operations of the new great men and by recuperating for them terms such as aequitas, repeatedly appropriated during the turbulent years of the Republic's demise. ${ }^{66}$ Moreover, Horace's private discretion-indeed his very preoccupation with the private rather than the public-masks the accumulation of power, and concentrates good attention on Maecenas and his friend Octavian. ${ }^{67}$

This discretion, however, which Horace has styled a "garden attitude," nibbles at the reader who comes to the book wanting juicy details about the inner workings of the inner circle. Lovers of Lucilian satire had come to expect as much, but Horace's readers, like the aspirant in Satires 1.9, are shooed away. Horace manages thus to satirize his readers even as he pokes fun at the aspirant and himself: mutato nomine de te / fabula narratur (1.1.69-70: change the name, and

64. Oliensis 1998: 20.

65. Oliensis 1998: 28.

66. See DuQuesnay 1984. DuQuesney argues that, though Horace disavows politics in the Satires, nevertheless his transformation of words such as libertas, aequitas, and amicitia into benign literary and social values associated with Maecenas and his friends helped ease their transition to power.

67. See Kennedy 1992. 
the story is told about you). Nevertheless, the poet does not always seem to be at ease with the discretion his relationship with Maecenas requires. In passing over delicate matters of personality and politics, his prudence, or refusal to speak, sometimes borders on inhibition, or inability to speak. Horace's reserve in his relationship with Maecenas is the hidden force behind Satires 1.8, another poem in Book 1 that ties together the city, sponsorship, status, and satire.

Satires 1.8 is an anecdotal account of a statue in Maecenas' Esquiline gardens, a fig-wood Priapus, whose sudden flatulence puts to flight some witches who have come to the gardens to conjure up the dead. Maecenas had purchased the Esquiline land, formerly a plebeian cemetery, early in the thirties and had transformed it into an outdoor sculpture park and garden. ${ }^{68}$ Maecenas himself lived in his gardens, and some evidence suggests Horace, Vergil and Propertius did as well. ${ }^{69}$ Horace's snapshot of a moment in Maecenas' estate is a bold choice with meaning deeper than the poem's anecdotal form suggests. Like Satires 1.5 and 1.9, which shed light on Maecenas by illuminating those around him, Satires 1.8 takes an indirect peek at Horace's benefactor, and explores in an oblique fashion the relationship between Horace's satiric poetry and his patron. Like Satires 1.9, Satires 1.8 reveals the discordance of Horace's poetic genre with his patron's generosity. In Satires 1.9, as we have seen, Horace presents satire as a genre more fitting for the city, where the poet can escape his new status and partake of the low, leveling tendencies of invective speech. In Satires 1.8, Horace explores from a different angle the incongruity of satiric poetry with Maecenas' patronage. Priapus, who has much in common with the poet, is transformed by the atmosphere of the gardens into a verbal eunuch: he can no longer employ the invective speech he normally would use. Just as this poem dramatizes the frustration of Priapus' priapism in the gardens (his phallus is ineffectual against the witch's threat), it hints at a similar frustration of Horace's satire.

In many ways Priapus' situation mirrors the poet's own. Anderson first noted the similarities between Priapus in Satires 1.8 and the besieged poet in Satires 1.9. Each is helpless, each responds with an outburst, and each has something to say about Maecenas' gardens. ${ }^{70}$ For Anderson, Priapus' successful purge of the witches demonstrates at once the salubrity of Maecenas' restored gardens (1.8.14) and the success of Horace's new, more refined style of satiric poetry. ${ }^{71}$ Just as the gardens are now free of the maleficent characters who used to frequent them, so too is Horatian satire now free of the caustic invective of former times: Satires 1.9's poet is not caustic, but polite to comic extreme. Whereas Anderson believes

68. See Häuber 1990, and Bell 1998.

69. See note 18 above.

70. Anderson 1982: 82: "I shall not go so far as to call Priapus a comic version of Horace, although I would not reject such a suggestion." Habash 1999 also sees in Priapus a voice for the poet, but for very different reasons: Horace imagines himself as the god in a parody of an autobiographical hymn.

71. Anderson 1982: 75-82, esp. 79-80. 
the tone of these two poems to be celebratory, I believe the poet's presentation of Maecenas' gardens in Satires 1.8 contains undercurrents of the tension between Horace's poetry and his patron, similar to that explored above for Satires 1.9.

The strongest connection between Priapus and the Horatian persona is the style of abusive speech they normally employ. In Satires 1.8 Priapus links Horatian satire with ithyphallic invective via the Priapea, a body of ribald poems from the Augustan age featuring the god Priapus and his phallus. ${ }^{72}$ This linkage implicates Horatian satire in a discourse that, in order to empower itself, abuses others. In Satires 1.8 that "other" is Canidia, a witch-crone whose name, through canis and Canicula, evokes the scorching dangerous female sex drive. ${ }^{73}$ Priapus attacks and debases this threatening woman so as to reassert his own stifled masculine imperative. ${ }^{74}$ Despite his proud reference to his usual weapon, the phallus (obscenoque ruber porrectus ab inguine palus, 1.8.5: my red pole sticking out from my vulgar groin), ${ }^{75}$ in Canidia's presence Priapus resorts in the end to a fart. Because of his fear (horruerim, 1.8.45), the customary phallic invective of this god is blocked, reroutes itself, and escapes as a self-mocking gesture. ${ }^{76}$ Priapus' reaction betrays nothing short of impotence: his invective phallus is ineffectual against the threat Canidia's overheated, dried-up femininity poses to the god's masculinity.

Indeed Canidia is a textual prism that refracts Horace's own impotence in all its domains. She appears in a position of dubious honor in the Satires and Epodes, recurring in the text in locations of thematic importance. She ends both Satires 2 and the Epodes, a feature that casts her as an anti-dedicatee-in this case, an anti-Maecenas. ${ }^{77}$ Canidia's primary influence over the persona of these two collections is sexual. The poet's invective against her throughout the Epodes and in Satires 1.8 attempts to camouflage an undisguisable sexual lack. In the Epodes, as Fitzgerald has shown, this lack itself camouflages a potential inadequacy in the poet-patron relationship. ${ }^{78}$ Such inadequacy pervades Satires 1 as well, where it manifests itself as a variety of physical failings that occur when the poet is in Maecenas' presence, such as indigestion (1.5.6-7 and 49) and eye trouble (1.5.30 and 49). ${ }^{79}$ Though Horace's eye problems may connote deference, it is significant that the poet chose to represent this deference as a personal physical failure. The

72. See Richlin [1983] 1992, particularly 116-43 and 174-85.

73. Oliensis 1991: 121-22; cf. Oliensis 1998: 73-74.

74. Henderson 1989: 60-63.

75. Indeed Priapus' self-description in 1.8.5-7 contains other phallic images; see Henderson 1989: 60 .

76. For a different view of Priapus' fear see Hallett 1981: 342.

77. See Oliensis 1991.

78. Fitzgerald 1989. See also Oliensis 1997 a for a broader overview of the sexual-textual slide in artistic amicitia in the Augustan age.

79. The effect of bleary eyes is confirmed in 1.3.25, in which Horace blasts the man who sees his own faults with smeared eyes, but others' with hawk-like acuity. Eye trouble is therefore a means for ignoring faults. 
same may be said for his indigestion. Deference to his patron spells infirmity for the poet.

Another symptom of Horace's debility with respect to his patron is the failure of speech he experiences in Maecenas' presence. In 1.6.49-64, the famous passage in which the satirist describes his introduction to Maecenas, he presents his own obstructed voice:

ut veni coram, singultim pauca locutus, infans namque pudor prohibebat plura profari....

When I came to you face-to-face, tongue-tied, I said few things, since inarticulate modesty prohibited me from saying more....

Horace is tongue-tied (singultim) in Maecenas' presence, and what is more, the modesty that prevents his speech is infans: both speechless and newborn at the same time. ${ }^{80}$ Since Maecenas is cast as a father-figure in this poem (1.6.61: abeo, et revocas nono post mense, I go away, and after nine months you call me back), Horace's reduction to infant-like silence is significant. It contrasts with the speech-enabling effect that Horace's natural father has on the poet. In 1.4.103-37, Horace describes the connection between his real father, his satiric poetry, the city, and his adulthood. The pater optimus gave Horace satiric examples by which he matured as a person and out of which he developed his satiric poetry. "Father" Maecenas, on the other hand, rather than inspiring satiric speech that is the mark of Horatian adulthood in Satires 1.4, reduces the poet to infantile silence. That the "real" father is constructed out of literary allusions ${ }^{82}$ only adds to my argument; Horace invents a natural father whose urban guidance fosters satire, and a foster father whose suburban sponsorship hinders it. Horace's description of his stammering meeting with Maecenas in Satires 1.6 (singultim, infans) and Priapus' circumlocution in Satires 1.8 (pepedi) reverberate in Horace's outburst of 1.9.48-52, where the poet's description of Maecenas' estate is marked by broken sentences and contorted word order, a "staged rupture of discursive norms." ${ }^{83}$ His interrupted sentences in that passage demonstrate the singultim ... infans pudor, the tongue-tied inarticulate modesty that he describes in Satires 1.6.

Priapus' blocked invective in Maecenas' gardens mirrors Horace's own blocked speech in Maecenas' presence. The gardens provide an environment antithetical to invective speech. Though they used to be the kind of sordid place

80. OLD s.v. infans, entries $1 . \mathrm{a} / \mathrm{b}$ and 2 .

81. Schlegel 2000: 113, exploring from a different perspective the discrepancy between Horace's doubled father in Book 1, reaches a similar conclusion: "... we should recognize that his claim of preferring his status as a son of a freedman over Maecenas' status functions above all poetically, to solidify the satiric poetry he is constructing."

82. See Leach 1971.

83. Oliensis 1998: 38; cf. Oliensis 1997b: 97. 
in which invective could flourish, Maecenas' renovation has made them too refined an environment to nurture it. Consider Priapus' position in the gardens, surrounded by elegant Greek marble.$^{84}$ Made of lowly figwood-cracked at that (1.8.1 and 47)-Priapus is certainly out of keeping with his setting. Priapus' invective, moreover, is as impotent as the figwood of which he is made: $:^{85}$

Cum mihi non tantum furesque feraeque suetae hunc vexare locum curae sint atque labori, quantum carminibus quae versant atque venenis humanos animos: has nullo perdere possum nec prohibere modo....

Since it is my duty and concern to watch out not so much for thieves and beasts accustomed to haunt this place as for women who turn human souls with spells and potions: I am not able to get rid of these women at all, nor even to get in their way....

Though it is his job to protect the gardens from intruders, Priapus fails.

Priapus' failure in the gardens echoes Horace's own inadequacy in Maecenas' presence, but it also comments on the humble position of satire among genres, perhaps even among the literary interests of Maecenas' circle of friends. Horace's outburst at 1.9.48-51 hints at satire's uncomfortable position in Maecenas' company, when he asserts that fault-finding, either social or poetic, has no place there (nil mi officit ... ditior hic aut est quia doctior). In the new gardens, as in the new political order, old-style libertas no longer indicates the ability to speak freely, as did Lucilius and the comic poets (1.4.5) ${ }^{86} \mathrm{In}$ deed libertas is a trait for which Horace must excuse himself (1.4.103). It is the emasculated Priapus' job to keep the gardens free from the evils of such licentious speech (carminibus ... atque venenis, 1.8.19, and cf. 1.9.50: nec magis his aliena malis). Canidia threatens the new condition of Maecenas' Esquiline estate, and perhaps more. Scholars have suggested that her presence in the gardens poses a contrast between past and present and exposes the fissures in the new order. Zetzel, for example, believes that Canidia's presence in the gardens "must be an embarrassment to Maecenas." ${ }^{77}$ To him, this poem is tactless, commemorating as it does the failure of Maecenas to rehabilitate this area. Anderson is more optimistic; he sees in this poem Horace's new satiric style supplanting the older "Canidian/Lucilian" style of invective

84. Bell 1998.

85. See Hallett 1981 for the associations of figwood with passive sexuality, particularly anal penetration.

86. See DuQuesney 1984 and Kennedy 1992 for the nuances of Horace's use of the word libertas in this collection.

87. Zetzel 1980: 71 with note 64. Jaeger 1990: 92ff. agrees, arguing that the witches in the gardens betray the difficulty of changing the past. 
poetry. ${ }^{88}$ Anderson finds a parallel in Satires 1.7, in which Rupilius Rex uses such old-style invective speech against Persius, who counters with a pun. For Anderson, Persius' pun-an example of a "more genial manner of laughter"routs Rex's poison (pus atque venenum, 1.7.1), thus announcing victory for Horatian satire over Lucilian invective. ${ }^{89}$ Exactly so, to Anderson, the fart of "the rather genial, inoffensive, easily shocked Priapus ... overcomes the evil witches and their ghoulish designs, thus preserving the creative, idyllic world of Maecenas' garden."90

Anderson is certainly right that Rupilius Rex in Satires 1.7, like Canidia in Satires 1.8, has something to do with Lucilian-style satire. Indeed, Persius and Rupilius both seem to be shadows of Horace. ${ }^{91}$ Yet Rupilius, contrary to Anderson's analysis, is perhaps the more admired of the two combatants, even though he loses the verbal spar to Persius. Persius is a practitioner of several verbal modes that are taboo in Horatian poetry, among them hybrid language, ${ }^{92}$ swollen style, ${ }^{93}$ and Asiatic excess. ${ }^{94}$ Rupilius Rex, on the other hand, exhibits some prime Horatian qualities. He is a speaker of much wit (salso multo, 1.8.28) and of Italian vinegar (Italo ... aceto, 1.8.32), elsewhere admired traits of Lucilian satire praised by the poet $(1.10 .3$, sale multo). ${ }^{95}$ Interestingly, like Priapus, Persius triumphs over Rupilius Rex with a form of circumscribed speech: a pun on Rupilius Rex' cognomen. The pun relies on a discrepancy between what is said and what is meant. As such, it is not straightforward: it "serve(s) as frustration of the delivery of signification."96

Canidia joins Rupilius Rex, then, as a purveyor of invective poetry. Though Horace finds several reasons to criticize satire's founding father, Lucilius' invective spirit is not one of them. Rather, he criticizes the older poet's wordiness and mongrel language - in short, his lack of refinement. The words used to describe Canidia's threat-carminibus ... atque venenis (1.8.19)_represent aspects of Lu-

88. Anderson 1982: 80-81.

89. Buchheit 1968, examining Horace's use of Homer in Satires 1.7 and 1.9, comes to a related conclusion: Homeric echoes, he argues, are used in such a way as to support Horace's sustained revision of Lucilius' poetic program.

90. Anderson 1982: 80-81.

91. Schlegel 1999 examines how Persius and Rupilius Rex both display Lucilian tendencies, in a poem that explores Horace's ambivalent attitude toward his generic ancestor.

92. hybrida Persius, 1.7.2, cf. 1.10.20-35, and recall that Horace, unlike Lucilius, translates Homer's Greek at 1.9.78 (Anderson 1982: 84-89).

93. confidens ...tumidus, 1.7.6-7, cf. the swollen river of 1.1.54-60.

94. laudat Brutum laudatque cohortem: /solem Asiae Brutum appellat, stellas salubris/appellat comites (1.8.23-25). See Freudenburg 1993: 158-59, who traces Horace's rejection of the Asiatic style.

95. See Gowers 1997: 127-28 for sal as a feature of Republican satire. Aristius Fuscus, the poet's good friend, partakes of sal as well (1.9.65, male salsus).

96. Henderson 1994: 151, and see Schlegel 1999 for an interpretation of the pun as the irresolution of the verbal combat in Satires 1.7. 
cilian satire that Horace approves and follows. ${ }^{97}$ The affinity between Canidia's verbal weapons in Satires 1.8 and Horace's generic pedigree renders her expulsion from the gardens stark. The poem marginalizes Canidia as a threatening, feminine "other," to be sure;" yet it also casts her as a shadow of the satiric poet, a potential but unfulfilled version of the satirist's own self whose denial (like the rejection of the aspirant of Satires 1.9) curbs the domain of Horace's satiric poetry. Because Canidia's style of poetry is inappropriate for Maecenas' cleaned-up estate (and the cleaned-up state), she is routed from the gardens which are fit now only for laughter and pleasantries (risuque iocoque, 1.8.50), and she flees into the city (currere in urbem, 1.8.47) where her talents are more at home. Like the map unfolding in the rest of the book, Satires 1.8 marks the city center as the appropriate locus for satiric speech, and the gardens of Maecenas as inimical to it.

In Maecenas' healthy estate (Esquiliis ... salubribus, 1.8.14), where competition, be it social or poetic, is absent (nil mi officit ... ditior hic aut est quia doctior, 1.9.49-50), Horace's satiric poetry is out of place, for it cannot focus its criticizing attention on the gardens or their inhabitants. The decorum of patronage requires that Horace show proper subordination to his benefactors. Yet the decorum of satire requires that the poet undermine status, stability, and authority. ${ }^{99}$ The poet cannot satirize Maecenas, yet by dramatizing the pressure Maecenas' friendship puts on his poetry, Horace manages to poke fun at him as well. How might Maecenas respond to the portrait of Horace reduced to baby-talk in his presence? While Horace professes that status is not an issue in Maecenas' circle, the poems reveal that status is always an issue.

Given that Maecenas is the addressee of Satires 1.1, and thus of the whole book, Horace's statement at 1.1.69-70 takes on new colors: mutato nomine de te / fabula narratur (change the name, and the story is told about you). The story is told about Maecenas, in part through the web of urban images in the Satires that sets Horace at odds with his poetry and his patron. Place in the city predicates and is predicated upon status. Satires 1.8 and 1.9, both anecdotes of blocked access to Maecenas, tell against social fluidity even while they advertise change in Rome's high society. ${ }^{100}$ In many ways a text for the new era, in their preoccupation with social mobility the Satires also glance grimly back at the turbulent final days of the Republic, in which wars were waged and lives lost over contests of status. ${ }^{101}$

This investigation points to some new directions in examining Horace's poetry. The same preoccupation with status pervades Horace's other poetry

97. Anderson 1982: 81 discusses the connection between Canidia's spells and poison and invective poetry.

98. Henderson 1989: 61.

99. Freudenburg 1993: 211-23, especially 211-12.

100. Henderson 1989: 80.

101. Likewise Leach 1997 argues that topographical references in Horace's second book of Odes demonstrate the persistence of the old status structure, rather than looking forward to a new era of new men. See also Dyson and Prior 1995: 260. 
from the thirties, Satires Book 2 and Epodes. A linkage of status with space might operate in those collections as well. A quick glance at Satires Book 2 demonstrates as much. In Satires 2.8, for example, seats at Nasidienus' table are carefully assigned to nine party-goers based on their various social pedigrees. ${ }^{102}$ At the microcosm of the dining table, status informs place. The same dynamic is applied to the macrocosm of the Italian countryside throughout Book 2, in which the opposition of urbs and rus takes the place of Book 1's contrast between urbs and rus-in-urbe.$^{103}$ The famous city mouse and country mouse in $2.6 .77-177$ play out Horace's social-spatial dilemma, on a grander (yet smaller!) scale. Both mice partake of aspects of the poet's persona, at odds with each other: the former cannot abide the country, nor the latter the city. ${ }^{104}$

The poet encapsulates his own dilemma in the first half of Satires 2.6: whether in the Forum or approaching the Esquiline, Horace's status makes him no longer a satiric poet, but instead a scion of Maecenas. Indeed, the fact that Horace speaks in so few of the poems in this book suggests that he sees himself as increasingly unfit for satire. It is telling that the Odes, while brimming with urban references, are equally as likely to highlight the country as the city. No longer a satiric poet, Horace does not need the vices of the city, and can afford to be away. Locations are not mere window-dressing in the Satires, but contribute to the poems' content as well as context. They provide a powerful set of images through which the poet can draw attention to the broader concerns of the work. In this case, place informs poetry, patron, and prestige.

University of Kansas

tswelch@ukans.edu

\section{BIBLIOGRAPHY}

Anderson, W.S. 1982. Essays on Roman Satire. Princeton.

Armstrong, D. 1986. “Horatius Eques et Scriba: Satires 1.6 and 2.7." TAPA 116: 255-88. Bell, M. 1998. "Le stele greche dell'Esquilino e il cimitero di Mecenate." In E. LaRocca, ed., Horti Romani, 295-314. Rome.

Braund, S. H. 1989. "City and Country in Roman Satire." In S. Braund, ed., Satire and Society in Ancient Rome, 23-48. Exeter.

Buchheit, V. 1968. "Homerparodie und Literarkritik in Horazens Satiren I 7 und I 9." Gymnasium 75: 519-55.

Byrne, X.N. 1996. Maecenas. Diss. Northwestern University. Evanston.

Castagnoli, F. 1952. "Note di Topografia Romana." Bull. Comm. Arch. Com. 74: 52-54.

102. Oliensis 1997b: 99.

103. Frischer 1995 examines the complex image of Horace's countryside villa in the context of Satires Book 2, finding this image a vehicle for the poet's continued meditation on status, morality, and luxury in the late Republic.

104. See West 1991. 
Cloud, D. 1989. "Satirists and the Law." In S. Braund, ed., Satire and Society in Ancient Rome, 49-68. Exeter.

Cody, J. 1976. "Satires 1.6 and 2.1: Horatian Moral Commitment and Callimachean Aesthetics." In Horace and Callimachean Aesthetics. Collection Latomus 147: 10319.

Courtney, E. 1994. "Horace and the Pest." CJ 90: 1-8.

DuQuesney, I. M. leM. 1984. "Horace and Maecenas: The Propaganda Value of Sermones I." In A. J. Woodman and D. West, eds., Poetry and Politics in the Age of Augustus, 19-58. Cambridge.

Dyson, S., and R. Prior. 1995. "Horace, Martial, and Rome." Arethusa 28: 245-64.

Fiske, G. C. 1920. Lucilius and Horace. A Study in the Classical Theory of Imitation. Madison.

Fitzgerald, W. 1989. "Power and Impotence in Horace's Epodes." Ramus 18: 179-91.

Fraenkel, E. [1957] 1966. Horace. Oxford.

Freudenburg, K. 1990. "Horace's Satiric Program and the Language of Contemporary Theory in Satires 2.1." AJP 111: 187-203.

. 1993. The Walking Muse. Princeton.

- 1996. "Verse-Technique and Moral Extremism in Two Satires of Horace (Sermones 2.3 and 2.4)." CQ 46: 196-206.

Frischer, B. 1995. "Fu la Villa Ercolanese dei Papiri un modello per la Villa Sabina di Orazio?" Chronache Ercolanesi 25: 211-29.

Gowers, E. 1993. “Horace, Satires 1.5: An Inconsequential Journey.” PCPS 39: 48-66.

. 1997. The Loaded Table: Representations of Food in Roman Literature. Oxford.

Griffin, J. 1984. "Augustus and the Poets: 'Caesar qui cogere posset.' " In F. Millar and E. Segal, eds., Caesar Augustus: Seven Aspects, 189-218. Oxford.

Habash, M. 1999. "Priapus: Horace in Disguise?" CJ 94: 285-97.

Hallett, J. 1981. "Pepedi / Diffisa Nate Ficus: Priapic Revenge in Horace, Satires 1.8." RhM 124: 341-47.

Hardie, P. 1993. "Ut pictura poesis? Horace and the Visual Arts." In N. Rudd, ed., Horace 2000: A Celebration, 120-39. Ann Arbor.

Häuber, R. C. 1990. "Zur Topographie der Horti Maecenatis und der Horti Lamiani auf dem Esquilin nach Rom." Kölner Jahrbuch 23: 11-107.

Henderson, J. 1989. "When Satire Writes 'Woman': Gendersong." PCPS 35: 50-80.

— 1993. "Be Alert: Your Country Needs Lerts." PCPS 39: 67-93.

- 1994. "Getting Rid of Kings: Horace Satires 1.7." CQ 44: 146-70.

Jaeger, M. K. 1990. The Poetics of Place: The Augustan Writers and the Urban Landscape of Ancient Rome. Diss. University of California, Berkeley. Berkeley.

Kennedy, D. 1992. “'Augustan' and 'Anti-Augustan': Reflection on Terms of Reference." In A. Powell, ed., Roman Poetry and Propaganda in the Age of Augustus, 26-57. London.

Knoche, U. 1971. Die Römische Satire. Göttingen.

Latacz, J. 1980. "Horazens sogenannte Schwätzersatire." AU 23: 5-22.

Leach, E. W، 1971. "Horace's pater optimus and Terence's Demea: Autobiographical Fiction and Comedy in Sermo 1.4." AJP 92: 616-32.

. 1997. "Horace and the Material Culture of Augustan Rome." In T. Habinek and A. Schiesaro, eds., The Roman Cultural Revolution, 105-21. Cambridge.

Nilsson, N. O. 1952. Metrische Stildifferenzen in den Satiren des Horaz. Uppsala. 
Oberhelman, S., and D. Armstrong. 1994. "Satire as Poetry and the Impossibility of Metathesis in Horace's Satires." In D. Obbink, ed., Philodemus and Poetry. Poetic Theory and Practice in Lucretius, Philodemus, and Horace, 233-54. Oxford.

Oliensis, E. 1991. "Canidia, Canicula, and the Decorum of Horace's Epodes." Arethusa 24: $107-38$.

- 1997a. "The Erotics of Amicitia: Readings in Tibullus, Propertius, and Horace." In J. Hallet and M. Skinner, eds., Roman Sexualities, 151-71. Princeton.

- 1997b. "Ut arte emendaturus fortunam: Horace, Nasidienus, and the Art of Satire." In T. Habinek and A. Schiesaro, eds., The Roman Cultural Revolution, 90-104. Cambridge.

- 1998. Horace and the Rhetoric of Authority. Cambridge.

Otto, A. 1890. Die Sprichwörter und sprichwörtlichen Redensarten der Römer. Leipzig. Pearcy, L. T. 1977. "Horace's Architectural Imagery." Latomus 36: 772-81.

Quinn, K. 1970. Catullus: The Poems. London.

Richlin, A. [1983] 1992. The Garden of Priapus. Sexuality and Aggression in Roman Humor. Oxford.

Rudd, N. 1961. "Horace's Encounter with the Bore." Phoenix 15: 79-96.

- [1966] 1982. The Satires of Horace. Berkeley.

Salmon, E. T. 1952. "Horace's Ninth Satire in its Setting." In M. White, ed., Studies in Honor of Gilbert Norwood, 184-93. Toronto.

Schlegel, C. 1999. "Horace Satires 1.7: Satire as Conflict Irresolution." Arethusa 32: 337-52.

- 2000. "Horace and his Fathers: Satires 1.4 and 1.6." AJP 121: 93-119.

Schmitzer, U. 1994. "Vom Esquilin nach Trastevere: Hor. Sat. 1,9 im Kontext Zeitgenössischen Verstehens." In S. Koster, ed., Horaz-Studien, 9-30. Erlangen.

Scodel, R. 1987. "Horace, Lucilius, and Callimachean Polemic." HSCP 91: 199-215.

Skinner, M. 1989. "Ut decuit cinaediorem: Power, Gender, and Urbanity in Catullus 10." Helios 16: 7-23.

Steinby, E. M. 1993. Lexicon Topographicum Urbis Romae. Rome.

Tosi, R. 1994. Dizionario delle sentenze Latine e Greche (dec. edizione). Milan.

Wallace-Hadrill, A. 1989. Patronage in Ancient Society. London and New York.

West, D. 1991. "Of Mice and Men: Horace, Satires 2.6.77-117." In A. J. Woodman and D. West, eds., Quality and Pleasure in Latin Poetry, 67-80. Cambridge.

White, P. 1978. "Amicitia and the Profession of Poetry in Early Imperial Rome." JRS 68: 74-92.

- 1993. Promised Verse: Poets in the Society of Ancient Rome. Cambridge.

Wickham, E. C. [1901] 1991. Q. Horati Flacci Opera. Oxford.

Zetzel, J. 1980. "Horace Sermones Liber 1: The Structure of Ambiguity." In Arethusa 13: 59-77.

- 1982. "The Poetics of Patronage in the Late First Century BC." In B. Gold, ed., Literary and Artistic Patronage in Ancient Rome, 87-102. Austin. 